Vol.46, n. 4 : pp. 529-536, December 2003 ISSN 1516-8913 Printed in Brazil
BRAZILIAN ARCHIVES OF BIOLOGY AND TECHNOLOGY

AN INTERNATIONAL JOURNAL

\title{
Copper Adsorption in Tropical Oxisols
}

\author{
Maria Lucia Azevedo Silveira* and Luís Reynaldo Ferracciú Alleoni \\ Universidade de São Paulo (USP); ESALQ; lrfalleo@esalq.usp.br; C. P. 9; 13418-900; Piracicaba - SP - Brazil
}

\begin{abstract}
Cu adsorption, at concentrations between 0 to $800 \mathrm{mg} \mathrm{L}^{-1}$, was evaluated in surface and subsurface samples of three Brazilian soils: a heavy clayey-textured Rhodic Hapludalf $(R H)$, a heavy clayey-textured Anionic "Rhodic" Acrudox (RA) and a medium-textured Anionic "Xanthic" Acrudox (XA). After adsorption, two consecutive extractions were performed to the samples which received $100 \mathrm{mg} \mathrm{L}^{-1}$ copper. Surface samples adsorbed higher amounts of Cu than the subsurface, and exhibited lower Cu removed after the extractions, reinforcing the influence of the organic matter in the reactions. $\mathrm{Cu}$ adsorption was significant in the subsurface horizons of the Oxisols, despite the positive balance of charge, demonstrating the existence of mechanisms for specific adsorption, mainly related to the predominance of iron and aluminum oxides in the mineral fractions. In these samples, $\mathrm{Cu}$ was easily removed from the adsorption sites. RH demonstrated a higher capacity for the $\mathrm{Cu}$ adsorption in both horizons.
\end{abstract}

Key words: Adsorption, isotherms, desorption, tropical soil

\section{INTRODUCTION}

Copper participates in the bio-ecological cycle and is essential for plant nutrition. However, when its concentration in the soil is high, it may become toxic to plants, animals and humans. Copper is a heavy metal, with density $8.96 \mathrm{~g} \mathrm{~cm}^{-3}$ (King, 1996). It may be present in lime, Pfertilizers, poultry litter, domestic and industrial residues and in organometallics, such as agrochemicals mainly used in agriculture. In residues, the amount of $\mathrm{Cu}$ depends upon the origin of the material and may reach values close to $8000 \mathrm{mg} \mathrm{kg}^{-1}$ in biosolids. The continuous use of these components in agriculture can cause the accumulation of $\mathrm{Cu}$ in the soil.

The solubility of $\mathrm{Cu}$ is controlled by adsorption/desorption reactions, precipitation and complexation. These interactions influence the partition of the metal in the liquid and solid soil phases and are responsible for its mobility and bioavailability in the system. The adsorption reactions which occur at the solid-liquid interface are an important mechanism for controlling the activity of heavy metals, not only in the soil solution, but also in natural water bodies (McLaren and Crawford, 1973; McBride et al., 1997; Salam and Helmke, 1998). The forms of adsorbed $\mathrm{Cu}$ control its concentration in the soil solution (Jordão et al., 2000). In this context, an understanding of the behavior of copper in the soil is fundamental for the prediction of the environmental consequences of its incorporation in the agroecosystem.

Copper has expressive affinity for certain functional groups in the colloid surface of soil components and can be complexed with both the organic and inorganic fractions. Iron, aluminum and manganese oxides and organic matter functional groups are most commonly involved in

\footnotetext{
* Author for correspondence
} 
the adsorption phenomenon of this metal. Due to the high selectivity of $\mathrm{Cu}$ for the reactive surfaces of soil colloids, stable molecules are formed (inner-sphere complexes), which result from specific adsorption, with high energy bonds and high stability (Sparks, 1995). Even if these active components are not present at high concentrations in the soil, they may be dispersed on the surface of sand and clay minerals, thus exerting considerable control upon the adsorption reactions.

Oxisols with acric properties are the result of an intense weathering and desilication processes, with the accumulation of iron oxides (hematite and goethite) and aluminum oxides (gibbsite), as well as kaolinite. Therefore, these compounds are usually found in the position of maximum accumulation of oxidic minerals (Uehara, 1988). According to FAO (1989), the acric character is defined when the soil exhibits an effective CEC of less than 15 mmol $_{\mathrm{c}} \mathrm{kg}^{-1}$ clay, as well as a $\mathrm{pH}(\mathrm{KCl}$ $\left.1 \mathrm{~mol} \mathrm{~L}^{-1}\right) \square 5$, or a $\Delta \mathrm{pH}\left(\mathrm{pH} \mathrm{KCl}-\mathrm{pH} \mathrm{H}_{2} 0\right) \square 0.1$ at $125 \mathrm{~cm}$ depth. In the State of São Paulo, Brazil, these soils are found mainly in northern region and support an intensive and technical agriculture based on the cultivation of sugar cane and in irrigated fields (Alleoni and Camargo, 1994). In tropical highly weathered soils, with an essentially oxidic mineralogy, $\mathrm{Cu}$ adsorption reactions seems to be distinct from those of soils of temperate climates.

Adsorption isotherms describe the relationship between the mass of the adsorbed substance (adsorvate) by the solid (adsorvent) and the concentration of the substance in the solution in equilibrium. One of the models used to describe the adsorption of elements is the Freundlich equation: $\mathrm{x} / \mathrm{m}=\mathrm{KC}$, in which $\mathbf{x}=$ mass of the element adsorbed; $\mathbf{m}=$ mass of the adsorvent solid phase; $\mathbf{C}=$ concentration of the equilibrium of the adsorvate in solution and $\mathbf{K}$ and $\mathbf{n}$ are empirically determined constants (Garcia-Miragaya and Page, 1976; Bowman et al., 1981). Another model used to describe metal adsorption is the Langmuir equation. When applied to minerals, sediments and soils, it is used in the form: $\mathrm{x} / \mathrm{m}=\mathrm{KbC} / 1+\mathrm{KC}$, in which $\mathbf{K}=$ parameter related to the affinity of the adsorvent by the adsorvate $\mathbf{b}=$ maximum adsorption.

Despite their limitations, the Freundlich and the Langmuir models have been used in various studies of $\mathrm{Cu}$ adsorption (Petruzzelli et al., 1985; Temminghoff et al., 1994; Yuan and Lavkulich, 1997; Jordão et al., 2000) and may be useful to predict the behavior of metals in the soil. The correlation coefficients obtained in these studies varied between 0.83 and 0.99 , indicating that these models are well adjusted to diverse soil conditions and metal concentrations.

One of the advantages of modeling is the possibility to express mathematically some of the soil properties, such as the nature of the adsorption processes (Jordão et al., 2000). Furthermore, the maximum adsorption parameter (Langmuir) may be used as an indicator to compare soil with different characteristics, as well as the effects of $\mathrm{pH}$ and organic material in the adsorption of the metal.

\section{MATERIAL AND METHODS}

Soil samples from a heavy clayey-textured Rhodic Hapludalf (RH), a medium-textured Anionic "Xanthic" Acrudox (XA) and a heavy clayeytextured Anionic "Rhodic" Acrudox (RA) clay were collected in São Paulo state, Brazil. The surface samples were collected from 0.0 to $0.2 \mathrm{~m}$ of the profiles, whereas the subsurface samples were collected from 1.0 to $1.4 \mathrm{~m}$ for the RA, 1.0 to $1.3 \mathrm{~m}$ for the XA, and 0.8 to $1.0 \mathrm{~m}$ for the $\mathrm{RH}$, representing the best expression of the $\mathrm{B}$ horizon. $\mathrm{RH}$ is less weathered when compared to the Oxisols, whose textures are contrasting.

Soils were air dried, passed through a 2-mm sieve and characterized according to Carmargo et al. (1986). Carbon content was quantified by the oxidation of the organic matter (OM) with potassium dichromate solution in the presence of sulfuric acid, followed by titration with ammonic ferrous sulfate. Amounts of iron oxides extracted with sulfuric acid were determined. Free and amorphous iron oxides were obtained after addition of sodium dithionite-citrate-bicarbonate and ammonium oxalate, respectively. The zero point of salt effect (ZPSE) was obtained by means of the titration method with $\mathrm{H}^{+}$and $\mathrm{OH}^{-}$at three $\mathrm{KCl}$ concentrations $\left(0.1 ; 0.01\right.$ and $\left.0.001 \mathrm{~mol} \mathrm{~L}^{-1}\right)$. The ZPSE was the $\mathrm{pH}$ value at the intersection point of the titration curves (Alleoni and Carmargo, 1994). The net charge was estimated from the titration curves. Permanent and variable charge densities were quantified according to Anderson and Sposito (1991), following saturation of the soil with $\mathrm{CsCl}$. The quantities of kaolinite and gibbsite were determined by differential 
thermic analysis. The $\mathrm{Ki}$ value was calculated after sulfuric attack according to the equation $\mathrm{Ki}=\left(\% \mathrm{SiO}_{2} / 60\right) /\left(\% \mathrm{Al}_{2} \mathrm{O}_{3} / 102\right)$.

To $2 \mathrm{~g}$ of fine soil (in triplicate) $20 \mathrm{~mL}$ of a solution of $0.0025 \mathrm{~mol} \mathrm{~L}^{-1} \mathrm{Ca}\left(\mathrm{NO}_{3}\right)_{2}$ containing $\mathrm{Cu}\left(\mathrm{NO}_{3}\right)_{2}$ at concentrations of $0 ; 5 ; 10 ; 20 ; 50$; $100 ; 200 ; 300 ; 400 ; 600$ and $800 \mathrm{mg} \mathrm{L}^{-1}$ copper were added. After shaking, $\mathrm{Cu}$ was determined in the supernatant by atomic absorption spectrophotometry. Copper adsorption was estimated by subtracting the value determined in the solution from the quantity initially placed in the equilibrium solution. Adsorption isotherms were constructed from the data obtained experimentally, plotting the quantity of copper adsorption in $\mathrm{y}$ and the equilibrium concentration in $x$ axis. In the samples which received $100 \mathrm{mg} \mathrm{L}^{-}$

${ }^{1}$ of $\mathrm{Cu}$, desorption was studied by means of two consecutive extractions with $0.01 \mathrm{~mol} \mathrm{~L}^{-1}$ $\mathrm{Ca}\left(\mathrm{NO}_{3}\right)_{2}$. The suspension was shaken for $24 \mathrm{~h}$ (Wu et al., 1999), centrifuged and the first measurement of $\mathrm{Cu}$ in the extract was taken. Another $20 \mathrm{~mL}$ of extracting solution was added, and the sample was shaken for $48 \mathrm{~h}$, following the procedure described previously. The period of 48 $\mathrm{h}$ is sufficient to guarantee the equilibrium of the samples (Atanassova, 1995). The second extraction was performed to extract any copper which may not have been previously desorbed. The experiment was conducted in a completely randomized design and statistical analyses were made using the SAS statistical program (SAS Institute, 1988).

\section{RESULTS AND DISCUSSION}

Values for the zero point of salt effect (ZPSE), presented in Table 1, were in agreement with those found in the literature (Alleoni, 1992; Guilherme and Anderson, 1998). The ZPSE in the subsurface samples of the Oxisols had higher values than the soil $\mathrm{pH}$, resulting in a positive balance of charge at this depth. RH had a negative charge in both horizons. The variable density of charges was predominant, particularly in the Acric Oxisols (Table 1). The highest values of density, both for variable and permanent charges, were found in RH. The low cation retention in Oxisols, notably in the subsurface horizons, where the OM had less influence, reflected the characteristic of highlyweathered soils. $\mathrm{Ki}$, as expected, was highest in the the $\mathrm{B}$ horizon of $\mathrm{RH}$, due to the lower degree of weathering. Kaolinite and gibbsite were the most predominant minerals found in the mineralogical analysis (Table 1). In Oxisols, gibbsite values were high (410 and $320 \mathrm{mg} \mathrm{kg}^{-1}$, for RA and XA, respectively). This characteristic has implications upon the magnitude of the electric charges in these soils, particularly in the subsurface horizons, where the $\mathrm{OM}$ contents are lower than in the surface layer.

$\mathrm{Cu}$ adsorption increased as $\mathrm{Cu}$ was added (Fig 1). The inclination of the adsorption curves showed that the increase in copper adsorption was higher at the lowest concentrations of the metal.

Table 1 - Soil chemical attributes

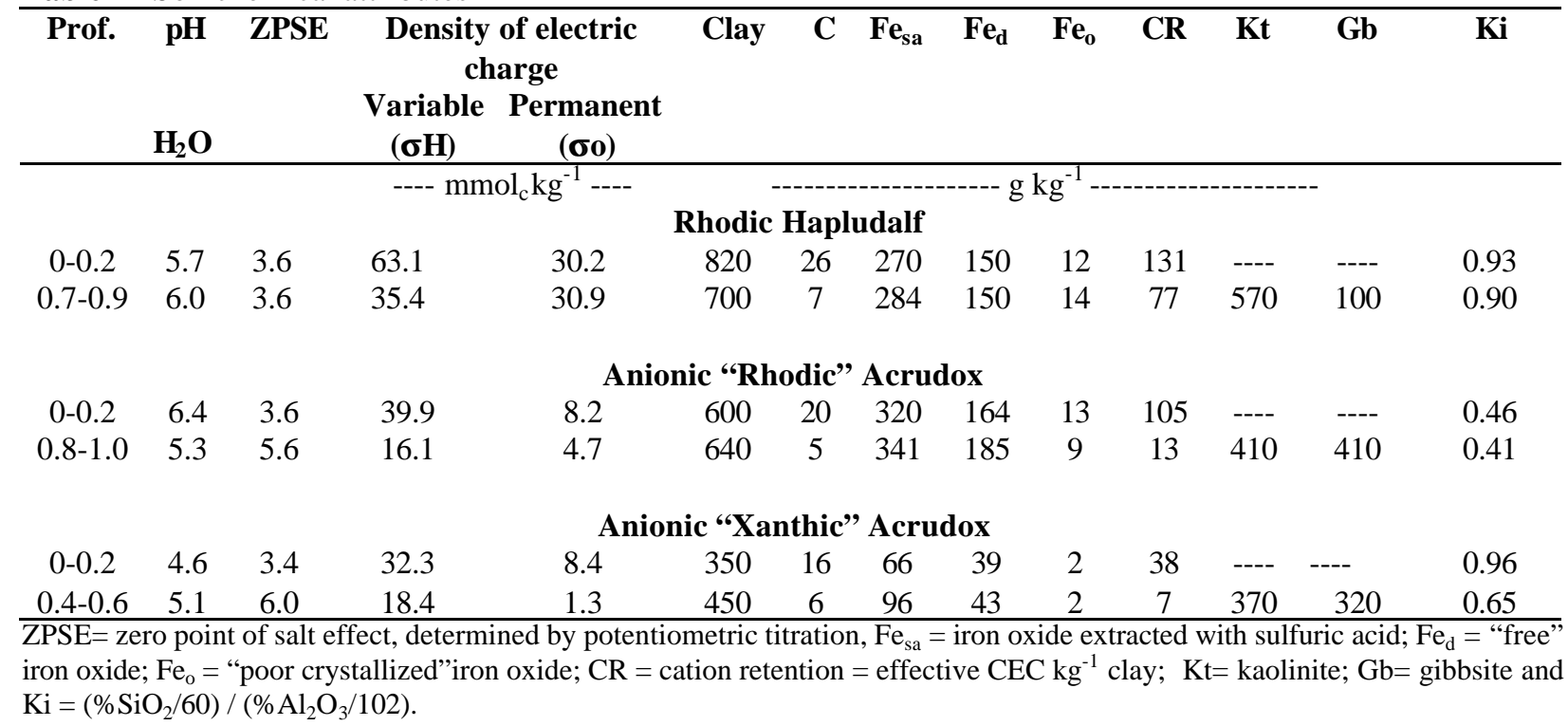




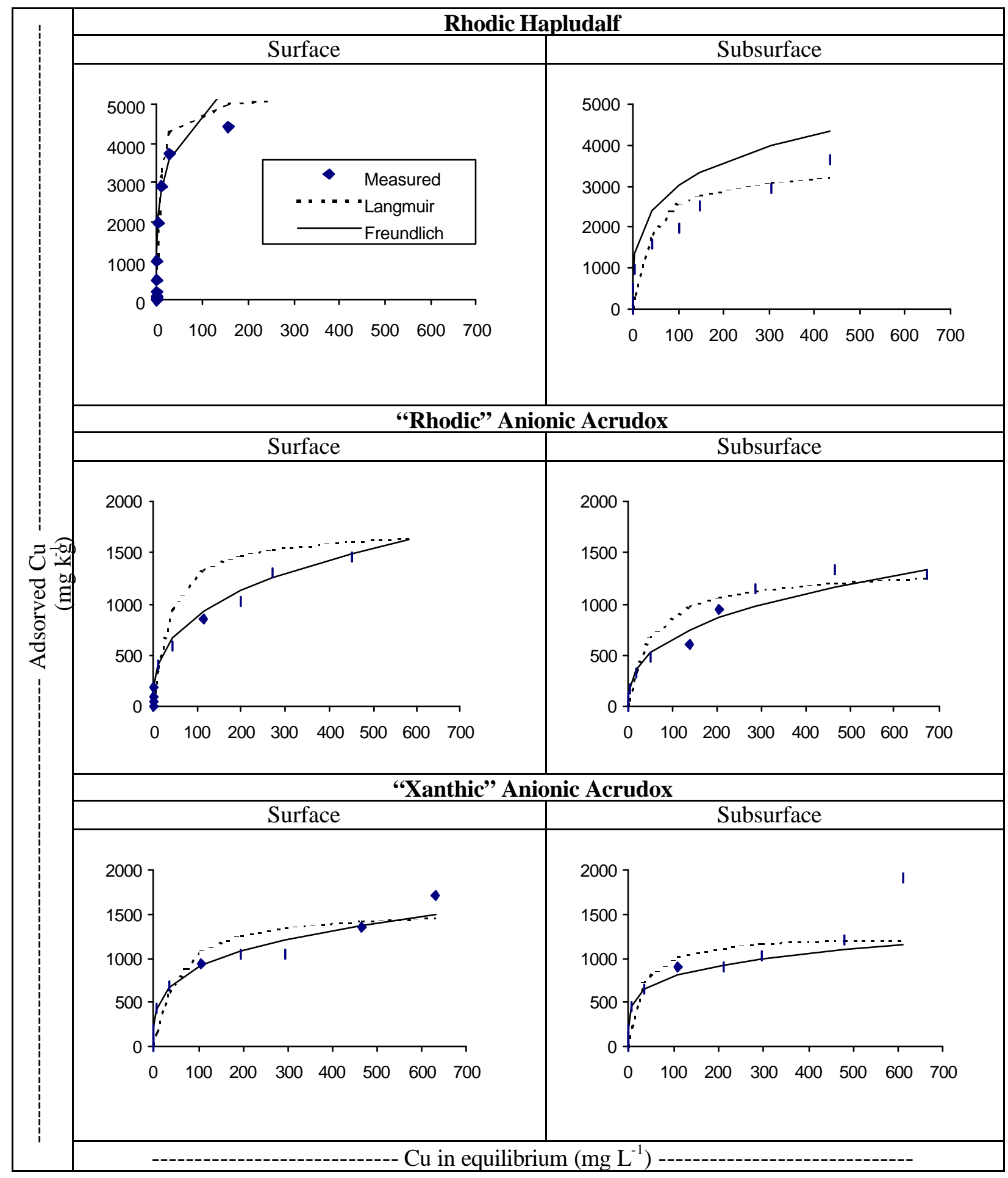

Figure 1 - Copper adsorption curves in surface and subsurface horizons.

As the concentrations increased, the increase in the adsorption was less pronounced. The process of $\mathrm{Cu}$ adsorption probably occurred in two stages, with the saturation of different adsorptive sites.
With the increase in the metal concentration, more sites were filled and $\mathrm{Cu}$ retention became more difficult (Petruzzelli et al., 1985). At the lower 
concentrations of added $\mathrm{Cu}$ (up to $20 \mathrm{mg} \mathrm{kg}^{-1}$ ), all $\mathrm{Cu}$ was adsorbed by the three soils.

In $\mathrm{RH}, \mathrm{Cu}$ adsorption was approximately $98 \%$ up to the concentrations of $100 \mathrm{mg} \mathrm{kg}^{-1}$ copper.

Choudhury and Khanif (2000) observed that $\mathrm{Cu}$ adsorption was not statistically different in three alluvial soils from Malaysia when concentrations varied from 200 to $500 \mu \mathrm{g} \mathrm{g}^{-1}$ of metal. At concentrations between 1 to $10 \mathrm{mg} \mathrm{kg}^{-1}, \mathrm{Cu}$ had a high affinity for the adsorption surfaces and could be completely adsorbed (Petruzzelli et al.,1985). Similar results were obtained by Jordão et al. (2000), who demonstrated the occurrence of two phases in the adsorption curve.

The initial phase of the adsorption curve corresponded to high bonding energy, although the soil had a low capacity for the adsorption of high quantities of the metal. In this case, although the soil adsorbed a lower quantity of copper, the energy which kept it adsorbed was sufficient for the metal not to be free in the system.

In a second phase, higher quantities of $\mathrm{Cu}$ are retained, although the retention energy is lower. Thus, each linear portion of the adsorption curve suggests different types of adsorption sites responsible for $\mathrm{Cu}$ retention in the soil.

The percentage of adsorbed $\mathrm{Cu}$ was higher in $\mathrm{RH}$, with mean values of approximately 83 and $77 \%$ in the surface and subsurface horizons, respectively. Oxisols had a lower capacity to retain $\mathrm{Cu}$; RA adsorbed approximately 61 and $53 \%$, in the surface and subsurface horizons, respectively, while XA adsorbed approximately 63 and $62 \%$, respectively. The maximum adsorption ("b" parameter in the Langmuir model) and the affinity constant in the Freundlich model demonstrated this behavior in RH. The highest maximum adsorption values were obtained in $\mathrm{RH}$, highlighting its higher capacity for retaining $\mathrm{Cu}$ in comparison to the Oxisols (Table 2). Similar results were obtained by Pombo and Klamt (1986) with an Ultisol and an Alfisol in Rio Grande do Sul, Brazil. In that study, the authors found higher values of adsorbed $\mathrm{Cu}$ in surface horizons from the Alfisol. Atanassova and Okazaki (1997) found higher values of maximum $\mathrm{Cu}$ adsorption in the soils with higher contents of $\mathrm{OM}$ and free $\mathrm{Fe}$ oxides. Although RH showed a higher clay content in relation to the acric Oxisols, the contents of free oxides was similar to that of the RA. The behavior in $\mathrm{RH}$ could, therefore, be related to the mineralogy, which is composed predominantly of kaolinite, the higher contents of $\mathrm{OM}$, and the negative balance of charge along the entire soil profile (Table 1).

Table 2 - Freundlich e Langmuir parameters.

\begin{tabular}{|c|c|c|c|c|c|c|c|}
\hline \multirow[t]{2}{*}{ Soil } & \multirow[t]{2}{*}{ Prof. } & \multicolumn{3}{|c|}{ Freundlich } & \multicolumn{3}{|c|}{ Langmuir } \\
\hline & & $\mathbf{K}$ & $\mathbf{N}$ & $\mathbf{r}$ & b & $\mathbf{K}$ & $\mathbf{R}$ \\
\hline \multirow{3}{*}{ RH } & $\mathrm{m}$ & & & & $\mathrm{mg} \mathrm{kg}^{-1}$ & $\mathrm{~mL} \mu \mathrm{g}^{-1}$ & \\
\hline & $0-0.2$ & $1,592.04$ & 0.25 & 0.99 & $5,199.94$ & 0.174 & 0.99 \\
\hline & $0.7-0.9$ & 950.65 & 0.25 & 0.99 & $3,505.61$ & 0.026 & 0.97 \\
\hline \multirow[t]{2}{*}{ RA } & $0-0.2$ & 187.87 & 0.34 & 0.97 & $1,733.35$ & 0.029 & 0.92 \\
\hline & $0.8-1.0$ & 123.73 & 0.37 & 0.99 & $1,344.51$ & 0.019 & 0.96 \\
\hline \multirow[t]{2}{*}{ XA } & $0-0.2$ & 255.14 & 0.27 & 0.98 & $1,583.17$ & 0.020 & 0.95 \\
\hline & $0.4-0.6$ & 312.25 & 0.20 & 0.90 & $1,268.44$ & 0.037 & 0.85 \\
\hline
\end{tabular}

Rhodic Hapludalf (RH), Anionic "Rhodic" Acrudox (RA) and Anionic "Xanthic" Acrudox (XA).

In all three soils, the percentage of $\mathrm{Cu}$ adsorbed was higher in the surface samples. The higher capacity for $\mathrm{Cu}$ adsorption in this layer was related to the higher $\mathrm{OM}$ content in this horizon. The decrease in the $\mathrm{Cu}$ retention capacity in the subsurface horizons was more expressive in the $\mathrm{RH}$ than in the Oxisols, probably due to the higher OM content in this soil. In soils, OM did not seem to be the main determinant of the retention of the metal by the soil. In RH, although the OM level in the subsurface horizon was similar to that of the Oxisols, higher $\mathrm{Cu}$ adsorption was observed, mainly as a result of the negative balance of charge at this depth. Langmuir and Freundlich affinity constants and the maximum adsorptions, calculated from the adsorption isotherms, were higher in the surface samples (Table 2). For example, the maximum $\mathrm{Cu}$ adsorption in $\mathrm{RH}$ surface was approximately three times that of the acrudoxes. 
The adsorption of copper was significant in the Oxisols, even though the subsurface horizons exhibited predominantly positive charges, due to the fact that the $\mathrm{pH}$ of the solution was lower than that of the respective ZPSE values (Table 1). Under these conditions, repulsion forces occur between the positive charges of the colloid surface and the $\mathrm{Cu}$, suggesting that not only mechanisms of electrostatic adsorption are involved in the process of metal adsorption by the soil. Mechanisms of specific adsorption are probably responsible for $\mathrm{Cu}$ retention, particularly in the subsurface horizons in the Oxisols. In this case, the presence of the $\mathrm{Fe}, \mathrm{Al}$ and $\mathrm{Mn}$ oxides and their respective hydrated forms stand out as the main groups responsible for the specific adsorption of the cations (Yu et al., 1997). Kuo and Baker (1980) reported that the $\mathrm{Cu}$ adsorption occurs even when the $\mathrm{pH}$ values of the soil are below the zero point of charge. In the XA, although the lower values of $\mathrm{CEC}$ and clay, $\mathrm{Fe}$ and $\mathrm{Al}$ oxides contents, the values of maximum adsorption were close to those found for the RA.

High correlation was found between the parameters obtained from the Freundlich and Langmuir equations and $\mathrm{Cu}$ adsorbed in soils (Table 2). Petruzzelli et al. (1985) also reported correlation coefficients for the Langmuir model of approximately 0.99 . Those authors observed that the Langmuir model fitted better for $\mathrm{Cu}$. Pombo and Klamt (1986), working with $\mathrm{Cu}$ concentrations between 0.5 and $34.4 \mathrm{mg} \mathrm{kg}^{-1}$, obtained determination coefficients for the
Langmuir model of 0.83 and 0.99 in two soils. Atanassova and Okazaki (1997) observed correlation coefficients of approximately 0.96 and 0.99 for the Langmuir and the Freundlich equations, respectively, in soils with different mineralogical compositions and physico-chemical properties. Yuan and Lavkulich (1997) found high correlation between the adsorption of copper and the " $\mathrm{K}$ " parameter of the Freundlich model $(\mathrm{r}=$ 0.98 to 0.99 ) for different soil samples. The values found in the present study were similar to those reported by Buchter et al. (1989). Those authors, in a study of 11 soils in the U.S.A. (some with chemical and mineralogical characteristics similar to those of tropical soils) and 15 chemical elements, related that $\mathrm{Cu}$ had the highest values of Freundlich constants, indicating a strong retention of the metal and high stability. The " $n$ " constant of the Freundlich model had values of between 0.47 and 1.42 (mean = 0.76), while the "K" constant varied between 54 and 6,353 $($ mean $=317)$. The high level of variation in these parameters is due to the different properties of the soils. The values for the " $K$ " parameter of the Langmuir model, indicating bond energy, are similar to those of the literature. Atanassova (1995) found values of 0.88 and 0.15 for this parameter in the surface horizons of two soils and a value of 0.034 in the B horizon. In the surface horizons of RH and XA, the first extraction was not sufficient to remove significant amounts of adsorbed $\mathrm{Cu}$, while in RA the decrease in adsorption was significant (Fig 2).
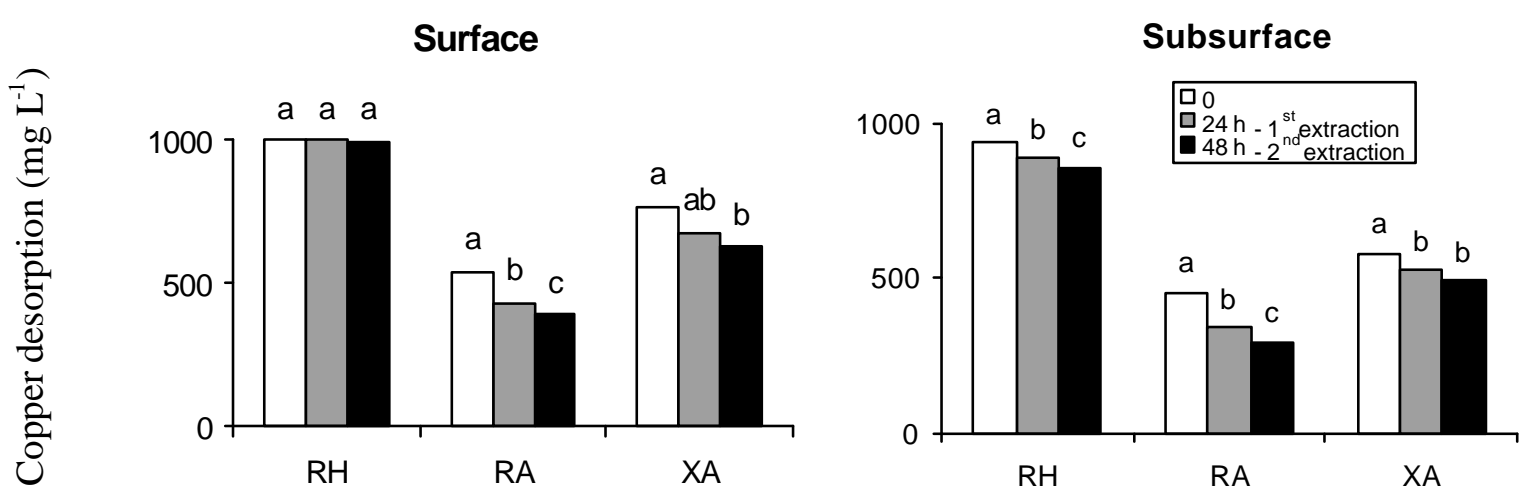

Figure 2 - Copper desorption after extraction with $\mathrm{Ca}\left(\mathrm{NO}_{3}\right)_{2}\left(0.01 \mathrm{~mol} \mathrm{~L}^{-1}\right)$ in the samples that received $100 \mathrm{mg}$ $\mathrm{L}^{-1}$ of the metal (for each soil, means followed by the same letter do not differ - Tukey $\mathrm{P}<0.05$ ). 
This difficulty in replacing $\mathrm{Cu}$ from the adsorption sites in RH and XA indicated that these soils had colloid surfaces with higher $\mathrm{Cu}$ retention affinities in relation to RA.

$\mathrm{Cu}$ desorbed after the first extraction probably comprised the exchangeable fraction. Following the second extraction, values of $\mathrm{Cu}$ adsorbed XA and RA decreased of approximately 18 and $28 \%$ in relation to the total adsorbed, respectively. In $\mathrm{RH}$, even after two extractions, the amount of adsorbed $\mathrm{Cu}$ did not differ statistically from the original sample, probably because of the higher bond energy of $\mathrm{Cu}$ in this soil. Conversely, in the subsurface samples of the three soils, the first extraction was enough to replace significant amounts of $\mathrm{Cu}$ bound to the colloid surface. In surface horizons, with higher contents of $\mathrm{OM}, \mathrm{Cu}$ was desorbed with more difficulty from the adsorptive sites, while at greater depth, the first extraction significantly reduced the amount adsorbed. After the second extraction, the quantities of adsorbed $\mathrm{Cu}$ were reduced even further, with the exception of XA. Following two extractions, 8,15 and $35 \%$ of the quantities of $\mathrm{Cu}$ were desorbed from the subsurfaces of RH, RA and XA, respectively. Atanassova (1995) obtained $35 \%$ desorption of $\mathrm{Cu}$ in $\mathrm{B}$ horizon of a Planosol. In the same study, $\mathrm{Cu}$ desorption was lower in the A horizon, reaching $18 \%$ of the total adsorbed.

In surface horizons, $\mathrm{Cu}$ was more strongly bound compared to the horizons of the subsurface, which is demonstrated by the fact that the metal was replaced with more difficulty than the sorptive complex. Similar results were obtained by $\mathrm{Wu}$ et al. (1999), who observed a higher $\mathrm{Cu}$ desorption in samples from which OM was removed, suggesting the existence of specific adsorption reactions between the copper ion and the organic material of the soil.

\section{CONCLUSIONS}

The effects of soil characteristics may influence $\mathrm{Cu}$ adsorption with different intensities. In tropical soils, with higher degrees of weathering and a predominance of oxidic mineralogy in the clay fraction, $\mathrm{Cu}$ adsorption reactions have different characteristics from those of soils with 2:1 mineralogy. Iron oxides are found at significant concentrations in these soils, conferring a surface composed mainly of variable charges. In the current study, in acric Oxisols, the CEC and the $\mathrm{Ki}$ values were the soil attributes that better correlated to $\mathrm{Cu}$ adsorption and the parameters of the Freundlich (K = affinity $-\mathrm{r}=0.83$ for CEC, and 0.97 for $\mathrm{Ki}$ ) and Langmuir ( $\mathrm{b}=$ maximum adsorption $-\mathrm{r}=0.89$ for CEC, and 0.96 for $\mathrm{Ki}$ ).

Rhodic Hapludalf soil exhibited a higher capacity for $\mathrm{Cu}$ adsorption than the Acric Oxisols. The surface samples adsorbed higher quantities of $\mathrm{Cu}$ in relation to the subsurface samples and had lower quantities of metal desorbed, demonstrating the influence of organic matter on the metal adsorption reaction. Freundlich and Langmuir adsorption models gave appropriate results for $\mathrm{Cu}$ adsorption at the concentrations used.

The charge balance in the soil, influenced by the levels of $\mathrm{OM}$ and clay and the mineralogical characteristics, particularly the iron and aluminum oxide and hydroxide contents, were the most important factors controlling $\mathrm{Cu}$ adsorption reactions in acric soils.

\section{RESUMO}

A adsorção de $\mathrm{Cu}$, nas concentrações de 0 a 800 $\mathrm{mg} \mathrm{L}^{-1}$, foi avaliada em amostras superficiais e subsuperficiais de três solos brasileiros: Nitossolo Vermelho eutroférrico (RH), textura muito argilosa; Latossolo Vermelho acriférrico (RA), textura muito argilosa; Latossolo Amarelo (XA) ácrico, textura média. Após a adsorção, realizaram-se duas extrações consecutivas nas amostras que receberam $100 \mathrm{mg} \mathrm{L}^{-1}$ de cobre. As amostras superficiais adsorveram maiores quantidades de cobre do que as subsuperficiais e exibiram menores quantidades de cobre removido após as extrações, o que evidencia a influência da matéria orgânica nas reações. A adsorção de cobre foi significativa nos horizontes subsuperficiais dos Latossolos, apesar do balanço positivo de cargas, demostrando a existência de mecanismos de adsorção específica, relacionados principalmente com a predominância dos óxidos de ferro e alumínio na fração mineral desses solos. Nestas amostras, o $\mathrm{Cu}$ foi mais facilmente removido dos sítios de adsorção. O RH apresentou maior capacidade de adsorção de cobre em ambos os horizontes. 


\section{REFERENCES}

Alleoni, L. R. F. (1992), Atributos eletroquímicos de solos ácricos do norte paulista. MSc Dissertation, Escola Superior de Agricultura "Luiz de Queiroz", Universidade de São Paulo, Piracicaba, Brazil. 123 pp.

Alleoni, L. R. F. and Camargo, O. A. (1994), Pontos de efeito salino nulo de latossolos ácricos. Rev. Bras. Ci. Solo, 18, 175-180.

Anderson, S. J. and Sposito, G. (1991), Cesiumadsorption method for measuring acessible strutural surface charge. Soil Sci. Soc. Am. J., 55, 1569-1576.

Atanassova, I. (1995), Adsorption and desorption of $\mathrm{Cu}$ at high equilibrium concentrations by soil and clay samples from Bulgaria. Environ. Pollution, 87, 17-21.

Atanassova, I. and Okazaki, M. (1997), Adsorptiondesorption characteristics of high levels of copper in soil clay fractions. Water Air Soil Pollution, 98, 213-228.

Bowman, R. S.; Essington, M. E. and O'Connor, G. A. (1981), Soil adsorption of Ni: influence of soil solution composition. Soil Sci. Soc. Am. J., 45, 860-865.

Buchter, B.; Davidoff, B.; Amacher, M. C.; Hinz, C.; Iskandar, I. K. and Selim, H. M. (1989), Correlation of Freundlich $\mathrm{Kd}$ e $\mathrm{n}$ retention parameters with soils and elements. Soil Sci., 148, 370-379.

Camargo, O. A.; Moniz A. C.; Jorge, J. A. and Valadares, J. M. A. S. (1986), Métodos de análise química, mineralógica e física de solos do IAC. IAC, Campinas, SP. 94 pp.

Choudhury, A. T. M. A. and Khanif, Y. M. (2000), Copper adsorption behavior of three Malaysian rice soils. Commun. Soil Sci. Plant Anal., 31, 567-579.

FAO (1989), Soil map of the world. Wageningem: ISRIC, (UNESCO. Technical Paper, 20). 138 pp.

Garcia-Miragaya, J. and Page, A. L. (1976), Influence of ionic strenght and inorganic complex formation on the sorption of trace amounts of $\mathrm{Cd}$ by montmorilonite. Soil Sci. Soc. Am. J., 40, 658-663.

Guilherme, L. R. G. and Anderson, S. J. (1998), Copper sorption kinetics and sorption hysteresis in two oxiderich soils (Oxisols). In: Venne, E. A. (Ed.). Adsorption of metals by geomedia: variables, mechanisms and model applications. San Diego : Academic Press. pp. 209-228.

Jordão, C. P.; Alves, N. M.; Pereira, J. L. and Bellato, C. R. (2000), Adsorção de íons $\mathrm{Cu}^{2+}$ em Latossolo Vermelho-Amarelo húmico. Quím. Nova, 23, 5-11.

King, L. D. (1996), Soil heavy metals. In: Alvarez, V. H.; Fontes, L. E. F. and Fontes, M. P. (Eds.). O solo nos grandes domínios morfoclimáticos do Brasil. Viçosa : SBCS. pp. 823-836.

Kuo, S. and Baker, A. S. (1980), Sorption of copper, zinc and cadmium by some acid soils. Soil Sci. Soc. Am. J., 44, 969-974.
McBride, M., Sauvé, S. and Hendershot, W. (1997), Solubility control of $\mathrm{Cu}, \mathrm{Zn}, \mathrm{Cd}$ e $\mathrm{Pb}$ in contamined soils. European J. Soil Sci., 48, 337-346.

McLaren, R. G. and Crawford, D. V. (1973), Studies on soil copper II. The specific adsorption of copper by soils. J. Soil Sci., 24, 443-452.

Petruzzelli, G.; Guidi, G. and Lubrano, L. (1985), Ionic strength effect on heavy metal adsorption by soil. Commun. Soil Sci. Plant Anal., 16, 971-986.

Pombo, L. C. A. and Klamt, E. (1986), Adsorção de zinco e cobre de dois solos do Estado do Rio Grande do Sul. Rev. Bras. Ci. Solo, 10, 191-194.

Salam, A. K. and Helmke, P. A. (1998), The pH dependence of free ionic activities and total dissolved concentrations of copper and cadmium in soil solution. Geoderma, 83, 281-291.

SAS Institute (1988), SAS user's guide: release 6.03. Cary.

Sparks, D. L. (1995), Sorption phenomena on soils. In: Sparks, D. L. (Ed.). Environmental soil chemistry. San Diego : California. pp. 99-139.

Temminghoff, E. J. M.; Van Der Zee, S. E. A. T. M. and Keizer, M. G. (1994), The influence of $\mathrm{pH}$ on the desorption and speciation of copper in a sandy soil. J. Soil Sci., 158, 398-407.

Uehara, G. (1988), Acric properties and their significance to soil classification. Paper presented at $8^{\text {th }}$ International Soil Classification Workshop, Rio de Janeiro : Embrapa, SNLCS. pp. 19-22.

Yuan, G. and Lavkulich, L. M. (1997), Sorption behavior of copper, zinc and cadmium im response to stimulated changes in soil properties. Commun. Soil Sci. Plant Anal., 28, 571-587.

Yu, T. R.; Sun, H. Y. and Zhang, H. (1997), Specific adsorption of cations. In: Yu, T. R. (Ed.). Chemistry of variable charge soils. New York : Oxford University Press. pp. 140-174.

Wu, J.; Laird, D. A. and Thompson, M. L. (1999), Sorption and desorption of copper on soil clay components. J. Environ. Qual., 28, 334-338.

Received: October 29, 2001; Revised: July 12, 2002; Accepted: November 19, 2002. 